\title{
The Relationship Of Knowledge Of Pregnant Women To Compliance With Health Protocols During The Covid-19 Pandemic At The Kassi-Kassi Health Center Makassar In 2021
}

\author{
Nur Indah Noviyanti ${ }^{1 *}$, Hukmiyah Aspar ${ }^{2}$, Gusriani $^{3}$ \\ ${ }^{1}$ Midwifery Mayor, Health science Faculty, Borneo Tarakan University, North Of Kalimantan. \\ ${ }^{2}$ Midwifery Mayor, Pelamonia Institute Health Science, South Of Sulawesi \\ ${ }^{3}$ Midwifery Mayor, Health science Faculty, Borneo Tarakan University, North Of Kalimantan. \\ * Corresponding author: \\ Email:nurindah@borneo.ac.id
}

\begin{abstract}
.
at Kassi-Kassi Health Center Makassar in 2021.

The purpose of this study was to determine the relationship between knowledge of pregnant women and adherence to health protocols during the COVID-19 pandemic at the Kassi-Kassi Health Center Makassar.This study uses analytical research methods by carrying out a Cross Sectional Study approach to determine the relationship between knowledge of pregnant women and adherence to health protocols during the COVID-19 Pandemic at the Kassi-Kassi Health Center Makassar. With a population of pregnant women who perform ANC examinations at the Kassi-Kassi Health Center Makassar and the number of samples is 30 respondents using the Accidental Sampling technique.From the results of statistical tests using the Chi-Square (Continuity Correction) test, the value of (0.039) < (0.050) is obtained, so Ha is accepted and HO is rejected, this study shows that there is a relationship between knowledge of pregnant women and adherence to health protocols.
\end{abstract}

Keywords: Knowledge, Compliance, COVID-19

\section{INTRODUCTION}

Pregnancy and childbirth are the happiest moments for mothers in the world. Pregnant women are one of the special groups who are vulnerable to the Corona Virus Disease 19 (COVID-19). Going through pregnancy and preparing for childbirth during the COVID-19 outbreak can add to anxiety for pregnant women. As a result of this pandemic, there are restrictions on activities, including health services for pregnant women. Pregnant women are afraid to go to health facilities for fear of getting infected. This causes the visit of pregnant women in health services to decrease. Social distancing leads to uncertain changes. It is hoped that pregnant women will continue to carry out pregnancy checks during the COVID-19 outbreak such as following health protocols, using masks when leaving the house, applying proper sneezing and coughing etiquette, and washing hands using soap and running water wherever and whenever (1).Results Data from the WHO (World Health Organization), based on an analysis of 147 pregnant women, there were $8 \%$ who had severe symptoms and $1 \%$ 
were in critical condition. Initial characteristics when pregnant women are exposed to the Corona virus include fever (78\%), cough (44\%), muscle pain $(33 \%)$, general weakness $(22 \%)$, shortness of breath (11\%), and sore throat. (22\%) (Literature et al., 2020).

The results of Riskesdas (Basic Health Research) conducted by the Ministry of Health show that data on Antenatal Care coverage in Indonesia during the last 3 years period in 2012 - 2015 was 92.7\% in 2013 and 95.2\% in 2015 (Ningsih, 2020). From the Makassar City Health Office data in 2016, the coverage of the first visit for pregnant women (K1) was $100.52 \%$ where the target of 28,698 pregnant women made the first pregnancy check-up visit to health facilities as many as 28,846 so that the target exceeded $100 \%$ because the number of visits exceeded the target. specified pregnant women. When compared with the coverage of the fourth visit (K4) service for pregnant women, it is $95.87 \%$, where the target is 28,698 pregnant women who visit pregnancy check-ups 4 times to health facilities as many as 27,514 (2)There are several factors that influence antenatal care such as knowledge, attitude, education level, parity, occupation, economic status, husband's support and quality of antenatal care services. according to Rahmayanti's research, seen from their knowledge, most (48\%) have sufficient knowledge, but as many as $17 \%$ of pregnant women who have less knowledge in terms of antenatal care during the current COVID-19 pandemic. The limited knowledge of the mother is one of the factors that influence the mother's noncompliance in carrying out pregnancy tests (3).

Based on new rules during the COVID-19 pandemic by the government in ANC (Antenatal Care) services, namely 6 times normal pregnancy with details 2 times in the first trimester, 1 time in the second trimester, and 3 times in the third trimester. This is a reference for pregnant women and health workers in providing Antenatal Care services.It is hoped that the mother and fetus will continue to receive essential services, risk factors can be identified early, and access to emergency assistance and health workers can be protected from transmission of COVID-19 (4) One of the mother's independence during pregnancy is an important thing that must be considered during the COVID-19 period. Pregnant women are expected to be able to monitor their pregnancies, improve the health of themselves and their fetuses by utilizing the information in the $\mathrm{MCH}$ handbook (Mother and Child Cards), and be able to detect early complications or problems that could harm themselves and the fetus (5).conducting research on the relationship between knowledge of pregnant women and adherence to health protocols during the COVID-19 pandemic at the Kassi-Kassi Health Center Makassar.

\section{METHODS}

This study uses an observational analytic method with a Cross Sectional Study approach which aims to determine the relationship between knowledge of pregnant women and adherence to health protocols during the COVID-19 pandemic at the 
Kassi-Kassi Health Center Makassar. This research was conducted in May 2021 at the Kassi-Kassi Health Center Makassar 2021. The population in this study were all pregnant women who had antenatal visits at the Kassi-Kassi Public Health Center Makassar.The sample in this study were 30 respondents. Sampling in this study is by accidental sampling. The measuring instrument in this study is a questionnaire consisting of several questions and statements. The sampling technique was carried out by accidental sampling where the researchers selected respondents from all pregnant women who visited the population of Antenatal Care at the Kassi-Kassi Health Center Makassar and taken as many as 30 people to be used as samples. Data collection is done in the following ways:

\section{Primary Data}

The primary data in this study was obtained from the results of filling out questionnaires to the respondents \& processed into a Master Table, then obtained from the results of the Chi-square test in SPSS.

\section{Secondary data}

was obtained through recording the growth and development of infants and toddlers at the Kassi-Kassi Public Health Center, where data collection first asked for permission through a letter requesting data collection to the Puskesmas.

The analysis carried out on each variable from the results of the research taken was carried out to obtain an overview by describing each variable used in the study, namely in the form of a frequency distribution accompanied by an explanation based on the data in the frequency distribution table.

\section{RESULT AND DISCUSSION}

Table 1.Distribution of Respondents by Age in PKM Kassi-Kassi Tamalate 2021

\begin{tabular}{c|c|l}
\hline Age & $\mathrm{n}$ & $\%$ \\
\hline$\leq 20$ years old & 4 & 13,3 \\
$20-35$ years old & 25 & 83,3 \\
$\geq 35$ years old & 1 & 3,3 \\
\hline Amount & 30 & 100 \\
\hline
\end{tabular}

source: Data Primer

Primary Data Based on the table above, it is known that most of the respondents are aged 20-35 years as many as 25 people $(83.3 \%)$.

Tabel 2. Distribution of respondents by education at PKM Kassi-Kassi Tamalate in 2021

\begin{tabular}{c|l|l}
\hline Education & $\mathrm{n}$ & $\%$ \\
\hline No School & 1 & 3,3 \\
\hline Elementary & 3 & 10,0 \\
\hline
\end{tabular}




\begin{tabular}{c|c|c}
\hline $\begin{array}{c}\text { Junior high } \\
\text { school }\end{array}$ & 7 & 23,3 \\
\hline $\begin{array}{c}\text { Senior High } \\
\text { School }\end{array}$ & 14 & 46,7 \\
\hline Bachelor & 5 & 16,7 \\
\hline Amount & 30 & 100 \\
\hline
\end{tabular}

source: Data Primer

Based on the table, the majority of respondents have high school education with the number of 14 people $(46.7 \%)$.

Tabel 3. Distribution of Respondents by Occupation at PKM Kassi-Kassi Tamalate in 2021

\begin{tabular}{l|l|l}
\hline Occupation & $\mathrm{n}$ & $\%$ \\
\hline Housewife & 27 & 90,0 \\
\hline entrepreneur & 2 & 6,7 \\
\hline Civil Servant & 1 & 3,3 \\
\hline Amount & 30 & 100 \\
\hline
\end{tabular}

Sumber: Data Primer

Based on the table above, it is known that most of the respondents are part of the respondents 27 people work as IRT $(90.0 \%)$.

Tabel 4.Distribution of Respondents Based on Mother's Knowledge at PKM Kassi-Kassi Tamalate 2021

\begin{tabular}{l|l|l}
\hline Knowledge & N & $\%$ \\
\hline Good & 27 & 90,0 \\
\hline Not so good & 3 & 10,0 \\
\hline Amount & 30 & 100 \\
\hline
\end{tabular}

Sumber: Data Primer

Based on the table above, it is known that most of the respondents are knowledgeable good 28 people $(93.3 \%)$.

Tabel 5.Distribution of Respondents Based on Mother's Compliance at PKM Kassi-Kassi Tamalate 2021

\begin{tabular}{l|c|c}
\hline Compliance & $\mathrm{N}$ & $\%$ \\
\hline Obey & 26 & 86,7 \\
\hline Disobedient & 4 & 13,3 \\
\hline Amount & 30 & 100 \\
\hline
\end{tabular}

Source: Primary Data 
Based on the table above, it is known that there are 26 respondents who obey $(86.6 \%)$.

Tabel 6. Relationship of knowledge of pregnant women to compliance with health protocols during the COVID-19 pandemic at PKM Kassi-Kassi in 2021

\begin{tabular}{llllllll}
\hline \multirow{3}{*}{ Knowledge } & \multicolumn{3}{c}{ Obedience } & \multicolumn{5}{c}{ Total } \\
\cline { 2 - 8 } & \multicolumn{2}{c}{ Obey } & \multicolumn{3}{c}{ Disobedient } & & \\
\cline { 2 - 8 } & $\mathrm{n}$ & $\%$ & $\mathrm{n}$ & $\%$ & $\mathrm{n}$ & $\%$ & \\
\hline Good & 25 & 92,6 & 2 & 7,4 & 27 & 100 & \multirow{2}{*}{039} \\
Not So Good & 1 & 33,3 & 2 & 66,7 & 3 & 100 & 039 \\
\hline Total & 26 & 86,7 & 4 & 13,3 & 30 & 100 & \\
\hline Source
\end{tabular}

Source : Primary Data

Based on the table above, it shows that respondents who have good knowledge and obedient compliance as many as 25 people $(92.6 \%)$.

\section{CONCLUSION}

Based on the results of data analysis conducted on the research sample as many as 30 respondents, namely pregnant women who did Antenatal Care at the Kassi-Kassi Public Health Center Makassar.

\section{Knowledge of Pregnant Women}

Based on the knowledge of pregnant women, the number of respondents was 30 people. As for the results of the study in table 4.4 above, it is known that pregnant women who have good knowledge are 27 people (90\%) higher, while knowledge is less good as many as 3 people (10\%). During the COVID-19 pandemic, knowledge of pregnant women is one of the factors that encourage pregnant women to make ANC visits. In this study, knowledge of pregnant women is a factor that can influence the behavior of pregnant women. This is in line with the theory of Lawrence Green (1980). That a person's behavior is influenced by knowledge, the better his knowledge, the better his behavior (2)

\section{Obedience of Pregnant Women}

Based on the results of the compliance of pregnant women, the number of respondents was 30 people. As for the results of the study in table 4.5 above, it is known that pregnant women who have obedient compliance are 26 respondents (86.7\%) higher, while those who do not comply are 4 respondents $(13.3 \%)$. The results of research by Fatimah et al, (2021) show that individuals judge themselves to have complied with government rules and recommendations for various reasons, namely because of self-awareness, benefits, trust in the government and perceived threats (6).

\section{Results of Variable Relationship Analysis}

Based on the results of research conducted on 30 respondents in pregnant women obtained good knowledge and obedient compliance as many as 25 people $(92.6 \%)$. While pregnant women who have poor knowledge and obedient compliance are 1 person $(33.3 \%)$. This shows that there is a knowledge factor on health protocol 
compliance. Based on the table above, it shows that there are still 2 mothers with good knowledge but not obedient (7.4\%), while mothers with poor knowledge and nonobedient compliance are $66.7 \%$ ). From the results of the study, it was found that there was a relationship between mother's knowledge of health protocols and maternal compliance in its application. Most mothers who have good knowledge are obedient to health promotion. This is in line with the theory of Lawrence Green (1980) that a person's behavior is influenced by knowledge, the better his knowledge, the better his behavior.

The results of this study are also in line with the results of research conducted by (7) regarding community compliance with compliance with using masks as an effort to prevent COVID-19 disease in Ngoranggah. Where the research results have a good relationship in preventing COVID-19. It can be concluded that some pregnant women who have good knowledge mean that they have started to understand and understand the prevention of COVID-19 including always using masks when going out of the house, not gathering and diligently washing hands. So, knowledge plays a very important role in preventing COVID-19 and education is very influential on a person's knowledge which is related to health protocol compliance. In this study, it was also found that mothers who did not comply were caused by various factors, for example because mothers did not get information about COVID-19 and its prevention. where the results of the research indicate that a person's level of compliance is influenced by educational factors and is supported by other factors, namely gender, age, occupation (8).

\section{ACKNOWLEDGMENTS}

The author would like to thank the research and community service institute of the University of Borneo, Tarakan and the Research and Community Service Institute of the Pelamonia Institute of Health Sciences for granting permission to conduct the research. The author also expresses gratitude in particular to the head of the Kassi Public Health Center and the staff in helping to provide research data

\section{REFERENCES}

[1] Adventus, Jaya IMJ and M. Buku Ajar Promosi Kesehatan Universitas Kristen Indonesia. 1-107 p.

[2] Evayanti. Hubungan Pengetahuan Ibu Dan Dukungan Suami Pada Ibu Hamil Terhadap Keteraturan Kunjungan Antenatal Care (ANC) Di Puskesmas Wates Lampung Tengah. J Kebidanan, [Internet]. 2014;81-90. Available from: ttp://malahayati.ac.id/wp-content/uploads/2016/03/18-60-1-PB.pdf.

[3] Devi Pramita Sari and Nabila Sholihah. Hubungan Antara Pengetahuan Masyarakat Dengan Kepatuhan Penggunaan Masker Sebagai Upaya Pencegahan Penyakit Covid19 Di Ngronggah. Infokes J Ilm Rekam Medis dan Inform Kesehatan,. :52-55.

[4] RI K. Pedoman pelayanan antenatal, persalinan, nifas, dan bayi baru lahir di Era Adaptasi Baru. Jakarta; 2020. 
[5] Hutagaol IO, Arini A, Mujianti CM. Pandemic Impact of Covid 19 on Compliance of Mother for Pregnancy Reviews. J Ilm Kesehat. 2021;3(1):200-7.

[6] Fathimah. Kepatuhan Masyarakat Terhadap Pemerintah Selama Pandemi: Studi Eksplorasi. Bul Ilm Psikol. 2021;2(1):15.

[7] Azizah dan Rosyidah. Pengetahuan dan Praktik Bidan tentang Standar Pelayanan Kehamilan di Era Pandemi Covid-19'. J Issue Midwife. 2021;34-39.

[8] Suhartini L. Relationship Knowledge and The Level of Compliance with The Use of Masks During the Covid-19 Pandemic at Gatot Soebroto Hospital 2020. Matern Neonatal Heal J. 2021;2(1):1-5. 